Autora: Maria de Lourdes Caltabiano Magalhães Orientadora: Profa. Dra. Rosiane Mattar

Co-orientador: Prof. Dr. Luiz Camano

Tese apresentada à Universidade Federal de São Paulo - Escola Paulista de Medicina - para a obtenção do Título de Mestre em Ciências, em 6 de dezembro de 2004.

Objetivos: analisar características epidemiológicas e aspectos clínicos relevantes da gestação, parto e do recém-nascido de adolescentes e comparar as variáveis analisadas entre as gestantes precoces e tardias. Pacientes e Métodos: Em estudo transversal, analítico, avaliou-se 2.058 prontuários, sendo $322(15,7 \%)$ do grupo das precoces e $1.736(84,3 \%)$ das tardias, que parturiram na Maternidade Escola Assis Chateaubriand/UFC de 1 de janeiro de 2000 a 31 de dezembro de 2000 . Resultados: do total de partos, 25,9\% eram de adolescentes sendo a média de idade 17,2 anos. Dentre as gestantes adolescentes avaliadas, 35,5\% se declararam sem parceiro, sendo que $41,8 \%$ eram precoces e $31,4 \%$ tardias; $15,8 \%$ eram analfabetas ou possuiam o ensino fundamental incompleto e $29,7 \%$ referiam 8 ou mais anos de estudo, sendo que destas, $15,4 \%$ eram adolescentes precoces. O consumo de fumo, álcool e drogas ilícitas foi baixo e sem diferença estatística entre os dois grupos etários. Constatou-se que $73, \%$ eram primigestas e que houve diferença estatística quanto à reincidência de gestações, com índice de 6,8\% entre as precoces e 30,7\% entre as tardias. Quanto ao aborto, 4\% ocorreu entre as de me- nor idade e $8,4 \%$ nas de maior idade $(p=0,033)$. Avaliouse também que $88 \%$ das gestantes compareceram ao prénatal, sendo que $60 \%$ com número insuficiente de consultas. As intercorrências clinicas mais freqüentes foram a pré-eclâmpsias $(14,7 \%)$, anemia (13\%) e infecção do trato urinário $(6,4 \%)$, sem diferença estatística entre os grupos. Ocorreram $31,34 \%$ de cesáreas, sendo a préeclâmpsia a principal indicação nas duas faixas etárias ( $25 \%$ e $23 \%$, respectivamente). Avaliou-se também o recém-nascido das gestantes adolescentes e observou-se que o indice de prematuridade foi de $16,7 \%(20,2 \times 16 \%$, $\mathrm{p}=0,069)$ e o escore de Apgar $<7$ no $1^{\circ}$ minuto de $15,1 \%$ $(19,9 \times 14,2 \%, p=0,008)$. As outras variáveis avaliadas, como o escore de Apgar no $5^{\circ}$ minuto, adequação do peso à idade gestacional, malformações e morte neonatal, apresentaram indices baixos e sem diferença entre os grupos. Conclusões: as gestantes adolescentes precoces e tardias podem ser comparadas em relação à evolução da gestação, tendo ambas, características biológicas aceitáveis para desempenho obstétrico satisfatório.

PALAVRAS-CHAVES: Gravidez; Adolescência

Resumo de Tese

\title{
Repercussões materno-fetais de ratas diabéticas e não-diabéticas expostas àfumaça de cigarro de tabaco
}

\section{Maternal-fetal repercussions in diabetic and non-diabetic rats exposed to cigarette smoke}

Autora: Paula Helena Ortiz Lima

Orientadora: Profa. Dra. Débora Cristina Damasceno

Co-orientadora: Profa. Dra. Daisy Maria de Fávero Salvadori

Dissertação apresentada ao Programa de Pós-Graduação em Ginecologia, Obstetrícia e Mastologia da Faculdade de Medicina de Botucatu - UNESP, para obtenção do título de Mestre, em 18 de fevereiro de 2005.

Objetivo: avaliar a genotoxicidade (niveis de danos no DNA) em amostras de sangue total de ratas Wistar prenhes diabéticas expostas à fumaça do cigarro de tabaco e de seus respectivos recém-nascidos (RN), estabelecendo uma correlação entre os níveis de danos maternos e os de seus recém-nascidos. Material e Método: ratas Wistar não-diabéticas e não expostas à fumaça (controle) e ratas diabéticas expostas à fumaça do cigarro de tabaco foram acasaladas. No $21^{\circ}$ dia de prenhez, foram anestesiadas e mortas por dessangramento para retirada de sangue materno e fetal para análise da genotoxicidade utilizando o teste do cometa. Após laparotomia, foi realizada contagem dos pontos de implantação e de fetos vivos e mortos. Os RN foram classificados com peso adequado (AIP), pequeno (PIP) e grande (GIP) para idade de prenhez. Resultados e Discussão: a associação do diabete grave e da exposição à fu- maça do cigarro de tabaco (associação) diminuiu o número de implantações e fetos vivos, mas o aumento na porcentagem de perda pós-implantação não foi significativo em relação ao grupo controle. A associação está relacionada à redução na porcentagem de RN AIP e GIP e prevaleceu PIP. Além disso, houve aumento de danos no DNA nas amostras de sangue total materno e de seus respectivos RN. No entanto, não houve correlação entre a genotoxicidade materna e dos recém-nascidos, sugerindo que, no organismo materno, estejam ocorrendo danos no DNA que podem ser detectados pelo teste do cometa, enquanto que, no organismo fetal, atividades mutagênicas tenham se iniciado, não sendo detectadas pelo teste do cometa nas condições empregadas.

PALAVRAS-CHAVE: Diabete melito; Teste do cometa; Tabagismo

Rev Bras Ginecol Obstet. 2005;27(6):366 